\title{
Carcass traits and meat quality of steers on pasture submitted to different dietary supplementation
}

\author{
Características de carcaça e qualidade de carne de novilhos \\ submetidos a diferentes estratégias de suplementação
}

\author{
Bruna Biava de Menezes $^{1 *}$; Henrique Jorge Fernandes²; Maria da Graça Morais ${ }^{3}$; \\ Edneia Pereira Rosa ${ }^{1}$; Andrea Roberto Duarte Lopes Souza ${ }^{4}$; Gelson Luis Dias \\ Feijós; Gumercindo Loriano Franco ${ }^{3}$
}

\begin{abstract}
This study aimed at evaluating carcass traits and meat quality of Nellore steers on pasture submitted to different dietary supplementation strategies. The 32 Nellore animals tested ( $8 \pm 0.6$ months) were raised under rotational grazing on Brachiaria brizantha cv. Piatã (syn. Urochloa brizantha cv. Piatã) pasture and distributed in four treatments: supply of mineral salt ad libitum in the growth and finishing phases (MSGF); concentrate supplementation only during the growth phase (CG); concentrate supplementation only during the finishing phase $(\mathrm{CF})$ and concentrate supplementation the growth and finishing phases (CGF). The concentrated supplement was supplied at $0.5 \%$ of body weight and mineral ad libitum. The steers were slaughtered when more than $50 \%$ of the lot of each treatment reached 450 $\mathrm{kg}$ body weight. The mean the hot and cold carcass weight and subcutaneous fat thickness did not differ between treatments $(\mathrm{P}>0.05)$. The calves the treatment $\mathrm{CF}$ and CGF showed a larger rib-eye area and higher ether extract levels in the Longissimus dorsi muscle than in MSGF and CG $(\mathrm{P}<0.05)$. Mean shearing force was similar between treatments $(\mathrm{P}>0.05)$. The use of feeding strategies on pasture with concentrate supplementation in the growth and finishing phases of Nellore cattle anticipates slaughter in 92 days and produces carcasses and meat with satisfactory traits.
\end{abstract}

Keywords: Beef cattle. Carcass composition. Commercial cuts. Longissimus dorsi.

\section{Resumo}

Objetivou-se avaliar as características de carcaça e qualidade de carne de novilhos Nelore submetidos à diferentes estratégias de suplementação à pasto. Foram utilizados 32 bezerros Nelore (idade inicial de $8 \pm 0,6$ meses) mantidos em pastagem Brachiaria brizantha cv. Piatã (syn. Urochloa brizantha cv. Piatã) manejados em sistema rotacionado e distribuídos em quatro tratamentos: suplementação com

\footnotetext{
${ }^{1}$ Discentes, Curso de Doutorado do Programa de Pós-Graduação em Ciência Animal, Faculdade de Medicina Veterinária e Zootecnia, Universidade Federal de Mato Grosso do Sul, UFMS, Campo Grande, MS, Brasil. E-mail: bruna_biava@hotmail. com; neiaros@hotmail.com

2 Prof. Dr., Departamento de Zootecnia, Universidade Estadual de Mato Grosso do Sul, UEMS, Aquidauana, MS, Brasil. E-mail: henrique.uems@hotmail.com

3 Profs. Drs., Departamento de Zootecnia, Faculdade de Medicina Veterinária e Zootecnia, UFMS, Campo Grande, MS, Brasil. E-mail: morais.mariazinha@gmail.com; gumercindo.franco@ufms.br

4 Pesquisadora, Programa de Desenvolvimento Científico Regional, DCR/CNPq/FUNDECT, Departamento de Zootecnia, Faculdade de Medicina Veterinária e Zootecnia, UFMS, Campo Grande, MS, Brasil. E-mail: andreardl_dagher@yahoo.com.br

5 Pesquisador, Empresa Brasileira de Pesquisa Agropecuária, EMBRAPA Gado de Corte, Campo Grande, MS, Brasil. E-mail: gelson.feijo@embrapa.br

* Author for correspondence
} 
sal mineral durante a recria e terminação (MSGF), suplementação com concentrado somente na fase de recria (CG), suplementação com concentrado somente na fase de terminação (CF) e suplementação concentrada durante a recria e terminação (CGF). O suplemento concentrado foi fornecido a $0,5 \%$ do peso corporal e o mineral ad libitum. Os animais foram abatidos quando mais de $50 \%$ do lote de cada tratamento atingiu $450 \mathrm{~kg}$ de peso corporal. Não foram observadas diferenças significativas entre as médias de peso da carcaça quente e fria e a espessura de gordura subcutânea de novilhos entre os tratamentos $(\mathrm{P}>0,05)$. Os animais do tratamento $\mathrm{CF}$ e CGF apresentaram maior área de olho de lombo e maior teor de extrato etéreo no músculo Longissimus dorsi do que os tratamentos MSGF e CG (P< $0,05)$. As médias de força de cisalhamento foram similares entre os tratamentos $(\mathrm{P}>0,05)$. O uso de estratégias de suplementação concentrada na fase de recria e terminação para novilhos Nelore criados à pasto pode antecipar o abate em até 92 dias, melhorar a composição física da carcaça e carne e garantir a produção de carcaças com características satisfatórias.

Palavras-chave: Composição de carcaça. Cortes comerciais. Gado de corte. Longissimus dorsi.

\section{Introduction}

The pasture grasses are the primary feed source for beef cattle in Brazil. However, nutrient availability in pastures varies throughout the year as a function of biomass and grass composition, affected by seasonality pasture production. The volume and nutritional value of the forage grass produced in the rainy season are adequate, but both are lower in the dry season (SILVA et al., 2017).

Thus, the greatest challenge to reduce beef production cycle in extensive system, in which predominates the Nellore breed animals and their crosses, is to accelerate growth and improve performance against the variations of supply and quality of the pasture. For this, the use of food supplementation (mineral and/or concentrate) has been used to correct the limitations of pasture quality and meet the nutritional requirements of animals the according to the phase (growth or finishing). The supply of nutrients via supplementation, aims to obtain different levels of performance for animals, providing from weight maintenance or moderate gains (155 to $325 \mathrm{~g}$ day $^{-1}$ )(SALES et al., 2011).

Although the recommendations regarding supplementation on pasture are well established in the literature, information about the influence of supplementation strategy (e.g., supplied continuously, only during growth or finishing) considering the slaughter fixed weight, carcass composition and meat quality produced are scarce.
Consider the slaughter weight fixed in experimental evaluations of beef cattle is relevant because it is the main information used by farms for the marketing of animals with to industry. In commercial farms, cattle lots usually have similar weights but different ages and this occurs due to the different feeding regime during weaning and slaughtering (CASAGRANDE et al., 2013). The age difference, however, has potential effects on meat composition and quality.

This study aimed at evaluating carcass traits and meat quality of Nellore calves in pasture submitted to different dietary supplementation strategies.

\section{Materials and Methods}

The experiment was conducted at the field of beef cattle in Aquidauana, MS, Brazil, latitude $20^{\circ} 28^{\prime} \mathrm{S}$, longitude $55^{\circ} 48^{\prime} \mathrm{W}$, elevation 149 meters, between the months of aug. 2013 and jan. 2015. Thirty-two Nellore animals were used, weighing 190.1 \pm 15.6 kgand with $8 \pm 0.6$ months average initial. The experiment was conducted after approval by the Federal University of Mato Grosso do Sul (UFMS) Ethics Committee on Animal Use (Protocol No. 004/2012) and the care and use of beef cattle were performed according to the standards for the use of animals in experiments.

The steers were weighed after weaning, identified and treated with anthelmintics, was 
used Ivomec Gold, one $\mathrm{ml}$ for each $50 \mathrm{~kg}$ of body weight. Over the experiment they were vaccinated according to the schedule determined by the Agência Estadual de Defesa Sanitária Animal e Vegetal (IAGRO).The animals were distributed in four treatments: mineral salt supplementation in the growth and finishing phases (MSGF), concentrate supplementation only in the growth phase (CG), concentrate supplementation only in the finishing phase $(\mathrm{CF})$ and concentrate supplementation during the growth and finishing phases (CGF). The growth phase lasted from 1 Aug 2013 to 10 Jan 2014, and the finishing phase from 11 Jan 2014 to Jan 2015. The steers were kept in the finishing phase until they weighed approximately $450 \mathrm{~kg}$. The concentrate supplementation was supplied at $0.5 \%$ of body weight (Table1), with monthly adjustments as a function of weight gain, after of each monthly weighing.

Table 1. Chemical composition of Urochloa brizantha cv. Piatã and concentrate supplement in base of dry matter.

\begin{tabular}{lcccccc}
\hline \multirow{2}{*}{\multicolumn{1}{c}{ Components, $\mathbf{g ~ k g}^{-1}$}} & \multicolumn{2}{c}{ Concentrate supplement } & & \multicolumn{2}{c}{ Urochloa brizantha cv. Piatã } \\
\cline { 2 - 3 } \cline { 5 - 6 } & Growth & Finishing & & Growth & Finishing \\
\hline Dry matter & $905 \pm 2.3$ & $904 \pm 10.1$ & & $306 \pm 0.5$ & $299 \pm 6.1$ \\
Crude protein & $152 \pm 26.1$ & $178 \pm 11.7$ & & $110 \pm 9.9$ & $122 \pm 5.3$ \\
Ether extract & $13 \pm 4.2$ & $23 \pm 4.0$ & & $16.8 \pm 2.4$ & $19.1 \pm 2.9$ \\
Neutral detergent fiber & $81 \pm 28.2$ & $125 \pm 18.3$ & & $569 \pm 7.2$ & $579 \pm 48.1$ \\
Acid detergent fiber & $104 \pm 31.5$ & $99 \pm 18.3$ & & $328 \pm 11.2$ & $322 \pm 4.6$ \\
Lignin & $18,4 \pm 8.7$ & $16.3 \pm 6.8$ & & $69.3 \pm 54.3$ & $55.6 \pm 24.6$ \\
Non fibrous carbohydrates & $451 \pm 71.1$ & $485.7 \pm 82.2$ & & $252 \pm 2.5$ & $191 \pm 25.1$ \\
Total Nutrients Digestible & & $658 \pm 13.3$ & $739.4 \pm 38.3$ & & $661 \pm 51.4$ & $676 \pm 20.3$ \\
\hline
\end{tabular}

Mistura mineral provided during contained $211 \mathrm{~g}$ calcium, $90 \mathrm{mg}$ cobalt, $1150 \mathrm{mg}$ copper, $3000 \mathrm{mg}$ sulfur, $650 \mathrm{mg}$ fluorine, $65 \mathrm{~g}$ phosphorus, $90 \mathrm{mg}$ iodine, $5000 \mathrm{mg}$ magnesium, $400 \mathrm{mg}$ manganese, $10 \mathrm{mg}$ selenium, $106 \mathrm{~g}$ sodium and $2500 \mathrm{mg}$ zinc. Mineral supplementation was supplied ad libitum.

${ }^{1}$ Estimate by NRC (2000).

During the experiment, the animals were held in an 8 ha pasture, grazing on Brachiaria brizantha cv. Piatã (syn. Urochloa brizantha cv. Piatã). The area was divided into sixteen 0.5 ha paddocks, with rotational grazing every 7 days to eliminate possible differences in dry matter (DM) supply or forage grass quality between the paddocks. The forage mass supply throughout the experiment ranged from 0.589 to $1.859 \mathrm{t} \mathrm{DM} \mathrm{ha}^{-1}$ (ROSA, 2016). Each paddock was supplied with a waterer and three feeders. The forage grass was sampled monthly using grazing simulation (hand-plucking) and after subjected to chemical analyses. The forage samples were dried in a forced air ventilation oven at $65^{\circ} \mathrm{C}$ for $72 \mathrm{~h}$, milled and sieved through $1 \mathrm{~mm}$ mesh before being analyzed according to AOAC (1995).
The animals were slaughtered when more than $50 \%$ of the lot of each treatment reached $450 \mathrm{~kg}$ body weight. After an $18 \mathrm{~h}$ solid food fast the animals were weighed to obtain fasting body weight (FBW). Slaughtering was carried out in slaughterhouses ruled by federal laws on humanitarian slaughtering. After slaughtering, the carcasses were divided into two halves and weighed to obtain hot carcass weight $(\mathrm{HCW})$ and hot dressing ( $\left.\mathrm{HD}=\mathrm{HCW} / \mathrm{SBW}^{*} 100\right)$. The carcasses were then cooled for $24 \mathrm{~h}$ in a cold chamber $\left(4^{\circ} \mathrm{C}\right)$. Carcass characteristics and meat quality were evaluated using the left half carcasses.

After cooling, cold carcass weight (CCW) and $\mathrm{pH}$ were measured in the Semi membranosus. Fat distribution in the carcass was evaluated individually by an experienced taster who assigned 
scores between 1 and 5 to carcass taste, where 1 corresponded to lack of fat and 5 to excess fat (MULLER, 1987). Carcass conformation was also determined, with score of 1 attributed to a concave profile and 5 to a convex profile, as established by the Sistema Nacional de Tipificação de Carcaças Bovinas (BRASIL, 1989). The internal carcass length (ICL) was determined using a flexible metal measuring tape, from the anterior border of the first rib to the anterior border of the pubic bone. The carcass compactness index was calculated as the CCW to ICL ratio.

The hind quarters were saw between the 12th and 13th ribs to determine the rib eye area (REA). After tracing it on acetate paper and measuring it transversally, the image was digitized using DDA v.1.2 software (Instituto Federal Farroupilha, Santo Augusto, RS, Brazil) to calculate the area. Subcutaneous fat thickness (SFT) was determined with a caliper, and marbling was classified according to the reference scores of the beef quality grade USDA (1997), which ranges from trace (400) to abundant fat (900).

In the region of the 12th rib, subcutaneous fat color was determined using the HunterlabMiniscan XE Plus Colorimeter. The evaluation was based on the HunterLab color system, considering luminosity $\left(\mathrm{L}^{*}\right)$ ranging from zero (black) to 100 (white), parameter $\mathrm{a}^{*}$ from $-\mathrm{a} *$ (green) to $+\mathrm{a}^{*}$ (red) and parameter $b^{*}$ from $-b^{*}$ (blue) to $+b^{*}$ (yellow). After $24 \mathrm{~h}$ cooling, the carcasses were weighed, deboned and cut to determine primal cut yields (frontquarter and special hindquarter cuts). The front quarter was separated into shoulder clod, chuck and brisket point end. The special hindquarter cuts were rump skirt, topside, outside flat, rump, tenderloin, eye round, rump steak, top sirloin, knuckle and shank. Beef cut yield was obtained by the equation ((cut weight ( CCW) * 100).

The HH section, between the 9th and the 11th rib (HANKINS; HOWE, 1946) was removed to estimate carcass tissue composition. This section was fully dissected into the primary components (muscle, fat and bones) to determine their proportions in the carcass. Tissue proportion was used to estimate the physical composition of the carcass using the following Hankins and Howe (1946) equation:

Muscle: $\hat{\mathrm{Y}}=16,08+0,80 \mathrm{X}$

Fat: $\hat{Y}=3.54+0,80 X$

Bones: $\hat{\mathrm{Y}}=5.52+0,57 \mathrm{X}$

The Longissimus dorsi muscle (top sirloin) of each animal was used to evaluate beef quality. Two $2.5 \mathrm{~cm}$ thick muscle samples were collected close to the 12th rib, vacuum-packed and stored frozen until analyzed. One sample was used to determine $\mathrm{pH}$, thawing loss, color, marbling, cooking loss and tenderness.

The other was used to determine centesimal composition (dry matter, mineral matter, crude protein and ether extract). Cooking loss was calculated as the weight difference between the crude sample and the sample roasted in an electric oven with forced air circulation at $193^{\circ} \mathrm{C}$. The samples were roasted until the geometric center reached $71^{\circ} \mathrm{C}$. The samples were then cooled at room temperature to $28^{\circ} \mathrm{C}$, weighed, packed, identified and cooled at 2 to $5^{\circ} \mathrm{C}$ for $24 \mathrm{~h}$.

After cooling, the shear force of the roasted samples was determined as proposed by the American Meat Science Association - AMSA (1995). Six cylindric subsamples, $1.27 \mathrm{~cm}$ in diameter, were cut parallel to the fiber direction, using an electric bench drill. The shear force was assessed by a TA.XT plus texture analyzer for a 30 $\mathrm{kg}$ load. The final shearing force was determined from the averageof the sub-sample results.

The AOAC (1995) protocols were used to determine dry matter (DM), mineral matter (MM), ether extract (EE) and crude protein (CP). Data were subjected to analysis of variance for a completely randomized design. Mean treatment data were compared using the Tukey's test. The significance level was set 0.05 . The calculations were performed using SAS 9.2 software (SAS INSTITUTE, 2009). 


\section{Results and Discussion}

Supplementation strategies affected the number of days between post-weaning and slaughtering $(p<0.05)$. The animals from MSGF took longer to reach slaughter weight than in the other treatments $(p<0.05$, Table2). Animals supplemented with concentrate in the finishing phase $(\mathrm{CF})$ or in the finishing and growth phases (CGF) reached slaughter weight faster than in the other treatments. Compared to MSGF, the higher weight gain in CGF shortened the period between post-weaning and slaughtering by 92 days. Concentrate supplementation optimizes the weight gain potential of cattle fed pasture grass (ROSA, 2016), and in the present study it accelerated the time to reach the $450 \mathrm{~kg}$ slaughter weight.

Table 2. Slaughter body weight (SBW), hot carcass weight (HCW), hot dressing (HD), cold carcass weight (CCW), cold dressing (CD), cooling loss (CL), conformation, internal carcass length (ICL) and carcass compactness index (CI) of Nellore steers on pasture submitted to different strategies of supplementation.

\begin{tabular}{lcccccc}
\hline \multirow{2}{*}{\multicolumn{1}{c}{ Variables }} & \multicolumn{4}{c}{ Treatments $^{\mathbf{1}}$} & \multirow{2}{*}{ C.V. (\%) } & \multirow{2}{*}{ P-Value } \\
\cline { 2 - 4 } & MSGF & CG & CF & CGF & & \\
\hline Days post weaning & $506^{\mathrm{a}}$ & $477^{\mathrm{b}}$ & $448^{\mathrm{c}}$ & $414^{\mathrm{d}}$ & 3.82 & 0.042 \\
SBW, kg & 416 & 438 & 436 & 444 & 5.63 & 0.115 \\
HCW, kg & 238.19 & 244.5 & 244.69 & 256.75 & 7.27 & 0.201 \\
HD, \% & 56.07 & 55.77 & 57.15 & 57.88 & 3.24 & 0.105 \\
CCW, kg & 232.79 & 239.16 & 236.19 & 251.04 & 7.07 & 0.179 \\
CD, \% & 54.8 & 54.55 & 55.94 & 56.59 & 3.21 & 0.097 \\
CL, \% & 2.26 & 2.19 & 2.10 & 2.24 & 14.94 & 0.783 \\
Conformation & 3.1 & 2.6 & 2.7 & 3.5 & 22.05 & 0.054 \\
ICL, cm & 127.43 & 128.5 & 125.31 & 129.5 & 2.64 & 0.102 \\
CI, cm/kg & 1.12 & 1.1 & 1.07 & 1.05 & 5.73 & 0.171 \\
\hline
\end{tabular}

${ }^{1}$ Supplementation with mineral salt on growth and finishing phases (MSGF), Supplementation with concentrate on growth phase (CG), supplementation with concentrate on finishing phase (CF) and supplementation with concentrate on growth and finishing phases (CGF). Averages in the same line, followed by different letters, differ from each other by the Tukey test at the $5 \%$ level. C.V.: coefficient of variation.

Supplementation strategies showed no significant differences in hot carcass weight, hot dressing, cold carcass weight, cold dressing, cooling loss, conformation, internal carcass length and compactness index ( $p>0.05$; Table 2). These results were expected since they are characteristics associated with slaughter body weight (PEREIRA et al., 2009), which was similar across treatments $(\mathrm{p}>0.05)$.

Hot and cold carcass weight, hot and cold dressing and morphometric carcass measurements were close to those reported by Moreira et al. (2012) in a study of Nellore steers on pasture receiving supplementation and slaughtered at a similar body weight. Supplementation effects are usually assessed in studies that use age rather than weight as slaughter criterion, given that different types of supplements (mineral, energy and protein) affect the final body weight and carcass characteristics (BARIONI et al., 2010).

The carcass of the different supplementation strategies were also similar in terms of $\mathrm{pH}$, finishing level, color subcutaneous fat (CSF), subcutaneous fat thickness (SFT) and marbling ( $\mathrm{p}>0.05$; Table 3 ).

The $\mathrm{pH}$ values were close to 5.6-5.8, which, according to Luchiari Filho (2000), is adequate 
for fresh meat. The $\mathrm{pH}$ value affects meat quality and, directly or indirectly, its color, appearance, flavor, aroma, texture, water retention capacity and emulsifying capacity (RAMOS; GOMIDE, 2009). The other parameters (conformation, finishing, CST, SFT and marbling) were similar across supplementation strategies, which is justified by the same breed, gender and body weight of the steers (Table 2). Conformation was close to the value of 3.07 found by Moreira et al. (2012) in cattle slaughtered at 24 to 30 months old.

Table 3. The $\mathrm{pH}$ values, conformation, finishing, color subcutaneous fat (CSF), rib eye area (REA), subcutaneous fat thickness (SFT) and marbling of Nellore steers on pasture submitted to different strategies of supplementation.

\begin{tabular}{|c|c|c|c|c|c|c|}
\hline \multirow{2}{*}{ Variables } & \multicolumn{4}{|c|}{ Treatments $^{1}$} & \multirow{2}{*}{ C.V. (\%) } & \multirow{2}{*}{ P-value } \\
\hline & MSGF & CG & CF & CGF & & \\
\hline $\mathrm{pH} 24 \mathrm{~h}$ & 5.53 & 5.65 & 5.58 & 5.56 & 1.90 & 0.174 \\
\hline $\mathrm{REA}, \mathrm{cm}^{2}$ & $64.63^{\mathrm{b}}$ & $72.06^{\mathrm{b}}$ & $77.63^{\mathrm{a}, \mathrm{b}}$ & $88.83^{\mathrm{a}}$ & 13.83 & 0.001 \\
\hline Finishing level & 2.1 & 2.1 & 2.1 & 2 & 14.62 & 0.801 \\
\hline CSF - L* & $66.38^{\mathrm{a}, \mathrm{b}}$ & $71.49^{\mathrm{a}}$ & $65.37^{b}$ & $67.51^{\mathrm{a}, \mathrm{b}}$ & 6.12 & 0.032 \\
\hline CSF - $a^{*}$ & 15.41 & 9.64 & 16.89 & 12.29 & 42.04 & 0.074 \\
\hline CSF - b* & $24.39^{\mathrm{a}, \mathrm{b}}$ & $21.22^{\mathrm{b}}$ & $26.21^{\mathrm{a}}$ & $23.84^{\mathrm{a}, \mathrm{b}}$ & 14.87 & 0.006 \\
\hline SFT, mm & 1.59 & 2.05 & 1.85 & 1.72 & 38.14 & 0.583 \\
\hline Marbling & 404.17 & 437.50 & 429.16 & 433.33 & 6.03 & 0.063 \\
\hline
\end{tabular}

${ }^{1}$ Supplementation with mineral salt on growth and finishing phases (MSGF), Supplementation with concentrate on growth phase (CG), supplementation with concentrate on finishing phase (CF) and supplementation with concentrate on growth and finishing phases (CGF). Averages in the same line, followed by different letters, differ from each other by the Tukey test at the 5\% level. C.V : coefficient of variation.

Supplementation strategies affected the rib eye area (REA), which was $17 \%$ larger in CGF than in MSGF and CG $(\mathrm{p}<0.05)$. The increased energy and crude protein intake were sufficient to meet the maintenance and weight gain requirements and allow maximum muscle deposition during growth (ROSA, 2016). REA in CF did not differ from that of the other treatments $(\mathrm{p}>0.05)$. Machado et al. (2012) found an REA of 54 and $60.72 \mathrm{~cm}^{2}$ and SFT of 1.70 and $1.96 \mathrm{~mm}$ in cattle receiving mineral and concentrate supplementation, respectively, which is close to that reported in the present study.

Although the supplementation provided during growth and finishing contributed to increasing muscle deposition, it did not accelerate finishing and intramuscular fat deposition $(p>0.05)$. In the assessment of carcass fat color, $L^{*}$ and $b^{*}$ values were affected by the supplementation strategies. $\mathrm{L}^{*}$ was higher in $\mathrm{CG}$ than in $\mathrm{CF}(\mathrm{p}<0.05)$, but similar in MSGF, CG and CGF ( $>0.05)$, and $b^{*}$ was similar between MSGF and CGF ( $>>0.05)$, but higher in CF than in CG.

The value of $b^{*}$ (yellow intensity) varies with SFT or fat content. In the present study, however, SFT was similar across treatments $(\mathrm{p}>0.05)$. Average SFT was $1.80 \mathrm{~mm}$, which is close to the $2.17 \mathrm{~mm}$ reported by Barioni et al. (2010) for Nellore cattle slaughtered at 33 months of age.As such, the yellowish color observed in CF and CGF was likely associated with the higher fat proportion estimate in carcass (Table 4).

Bone proportion in the carcass did not differ between MSGF, CG and CGF ( $>00.05$ ), but was higher in MSGF than in CF $(\mathrm{p}<0.05)$. This suggests that mineral supplementation increased mineral availability for deposition in the bone matrix, likely 
because the diet became unbalanced (low in protein and energy) during forage shortage period, and the body prioritized the formation of tissues essential to its survival. Bone tissue is associated with early growth, supporting other body tissues and requiring little energy for minerals deposition in their matrix.

Table 4. Physical composition of carcasses of Nellore steers on pasture submitted to different strategies of supplementation.

\begin{tabular}{lcccccc}
\hline \multirow{2}{*}{\multicolumn{1}{c}{ Variables }} & \multicolumn{4}{c}{ Treatments $^{\mathbf{1}}$} & \multirow{2}{*}{ C.V. (\%) } & \multirow{2}{*}{ P-value } \\
\cline { 2 - 4 } & MSGF & CG & CF & CGF & & \\
\hline Bones of carcass, \% & $16.34^{\mathrm{a}}$ & $15.32^{\mathrm{a}, \mathrm{b}}$ & $14.49^{\mathrm{b}}$ & $15.10^{\mathrm{a}, \mathrm{b}}$ & 6.27 & 0.006 \\
Muscles of carcass, \% & 70.09 & 72.46 & 70.97 & 69.46 & 3.75 & 0.149 \\
Fat of carcass, \% & $14.35^{\mathrm{a}, \mathrm{b}}$ & $13.37^{\mathrm{b}}$ & $16.06^{\mathrm{a}, \mathrm{b}}$ & $16.74^{\mathrm{a}}$ & 16.14 & 0.039 \\
Muscles/fat & 4.96 & 5.56 & 4.78 & 4.19 & 24.05 & 0.159 \\
Muscles/bone & $4.32^{\mathrm{b}}$ & $4.75^{\mathrm{a}, \mathrm{b}}$ & $4.92^{\mathrm{a}}$ & $4.61^{\mathrm{a}, \mathrm{b}}$ & 8.64 & 0.038 \\
(Muscles+ fat)/bone & $5.20^{\mathrm{b}}$ & $5.62^{\mathrm{a}, \mathrm{b}}$ & $6.03^{\mathrm{a}}$ & $5.72^{\mathrm{a}, \mathrm{b}}$ & 7.81 & 0.008 \\
Fat/bone & $0.89^{\mathrm{b}}$ & $0.88^{\mathrm{b}}$ & $1.11^{\mathrm{a}}$ & $1.10^{\mathrm{a}}$ & 18.67 & 0.017 \\
\hline
\end{tabular}

${ }^{1}$ Supplementation with mineral salt on growth and finishing phases (MSGF), Supplementation with concentrate on growth phase (CG), supplementation with concentrate on finishing phase (CF) and supplementation with concentrate on growth and finishing phases (CGF). Averages in the same line, followed by different letters, differ from each other by the Tukey test at the $5 \%$ level. C.V : coefficient of variation.

The proportion of muscles in the carcass was similar across treatments ( $>0.05$; Table 4$)$, probably because the calves had already reached physiological maturity, regardless of the supplementation strategy. As the animal reaches adult weight and the physiological maturity, there is maximum muscle deposition, and then the protein deposition rate declines and adipose tissue deposition increases. However, the order of deposition of the tissues (bones $>$ muscles $>$ fat) is not modified overtime, but the intensity of their deposition is affected especially by nutritional management (OWENS et al., 1993).

As energy demands for body maintenance and protein production are meat, additional energy is redirected to fat deposition (NRC, 2000). The amount of fat deposited in the carcass depends on dietary energy intake and animal performance. This assumption was confirmed in the present study given that the fat ratio was higher $(p<0.05)$ in the carcasses of CGF steers than CG, which were supplemented with concentrate during growth and finishing. Carcass fat proportion was similar between MSGF and CG with the others supplementation strategies $(\mathrm{p}>0.05)$.

The muscle to bone ratio and muscle + fat to bone ratio were affected by the treatments, and were higher in CF than in MSGF $(\mathrm{p}<0.05)$. This result is compatible with the higher proportion of bones in MSGF $(p<0.05)$. In CG and CGF, the ratios were similar to those of the other treatments $(p>0.05)$.

The carcass of steers receiving concentrate supplementation in the different strategies tested had higher muscle and fat content than those receiving only the mineral mixture. This is explained by the higher nutrient supply provided by the concentrate throughout the experiment and irrespective of the season and forage availability. The higher nutrient content and digestibility of the concentrate supports growth acceleration and tissue development.

The levels of crude protein and available total digestible nutrients were similar across the concentrate supplement of growth and finishing (Table 1). Nevertheless, nutrient use was different between supplementation strategies with the 
concentrate and mineral salt in the each phase studied. Forage grass, which exhibits lower digestibility than that of the concentrate (ROSA, 2016), was the sole energy and protein source for animals provided only with mineral salt. According to Owens et al. (1993), diets with higher nutritional value can accelerate growth, change the age and weight for deposition of each body tissue and modify final body composition.

As in the present study, Machado et al. (2012) found that muscle and fat deposition was higher in the carcasses of cattle receiving on pasture concentrate supplementation $(63.63 \%$ muscle, $16.33 \%$ fat) than in those receiving mineral salt (62.23\% muscle, $15 \%$ fat). As such, body weight alone does not reflect carcass tissue composition in the present study. Muscle to fat ratio did not differ across treatments $(p>0.05)$. The supplementation strategies did not affect the yield of shoulder clod, chuck, topside, rump, tenderloin, eye round, rump steak, top sirloin, knuckle, rump skirt and shank cuts ( $\mathrm{p}>0.05$; Table 5).

Table 5. Yields of meat cuts of Nellore steers on pasture submitted to different strategies of supplementation.

\begin{tabular}{|c|c|c|c|c|c|c|}
\hline \multirow{2}{*}{ Meat cuts } & \multicolumn{4}{|c|}{ Treatments $^{1}$} & \multirow{2}{*}{ C.V. $(\%)$} & \multirow{2}{*}{ P-Value } \\
\hline & MSGF & CG & $\mathbf{C F}$ & CGF & & \\
\hline Shoulder clod, \% & 12.61 & 12.68 & 12.85 & 12.85 & 5.77 & 0.151 \\
\hline Chuck, \% & 13.85 & 13.34 & 13.64 & 13.63 & 8.3 & 0.616 \\
\hline Brisket point end, \% & $4.43^{\mathrm{b}}$ & $4.44^{\mathrm{b}}$ & $4.95^{\mathrm{a}}$ & $4.86^{\mathrm{a}, \mathrm{b}}$ & 7.53 & 0.008 \\
\hline Top side, $\%$ & 7.74 & 7.92 & 8.04 & 7.80 & 4.84 & 0.367 \\
\hline Outside flat, $\%$ & $3.72^{\mathrm{b}}$ & $3.92^{\mathrm{a}, \mathrm{b}}$ & $4.18^{\mathrm{a}}$ & $4.01^{\mathrm{a}, \mathrm{b}}$ & 7.25 & 0.093 \\
\hline Rump, \% & 3.2 & 3.33 & 3.29 & 3.18 & 6.98 & 0.158 \\
\hline Tender loin roast, $\%$ & 1.99 & 1.95 & 2.12 & 1.98 & 7.96 & 0.276 \\
\hline Eye of round roast, $\%$ & 2.28 & 2.16 & 2.14 & 2.19 & 8.63 & 0.379 \\
\hline Rumpsteak, \% & 1.84 & 1.80 & 1.82 & 1.66 & 11.13 & 0.948 \\
\hline Top sirloin, \% & 2.74 & 2.83 & 2.66 & 2.78 & 10.95 & 0.402 \\
\hline Knucle, \% & 4.28 & 4.3 & 4.44 & 4.27 & 4.94 & 0.375 \\
\hline Rump skirt, \% & 1.33 & 1.19 & 1.26 & 1.22 & 15.25 & 0.731 \\
\hline Shank, \% & 3.55 & 3.59 & 3.51 & 3.48 & 5.43 & 0.440 \\
\hline
\end{tabular}

${ }^{1}$ Supplementation with mineral salt on growth and finishing phases (MSGF), Supplementation with concentrate on growth phase (CG), supplementation with concentrate on finishing phase (CF) and supplementation with concentrate on growth and finishing phases (CGF). Averages in the same line, followed by different letters, differ from each other by the Tukey test at the $5 \%$ level. C.V : coefficient of variation.

In a study on cattle receiving mineral salt and increasing levels of concentrate supplementation (1, 2 and $\left.3 \mathrm{~kg} \mathrm{day}^{-1}\right)$ in the transition from the rainy to the dry season, Machado et al. (2012) found no treatment effects on commercial meat cut yield. In the present study, however, the treatments affected brisket point end and outside flat yields, which were higher in CF and CGF than in MSGF $(p<0.05)$. This result may be associated with the higher fat deposition in the carcass (Table 4).
Steers receiving concentrate likely achieved advanced physiological maturity earlier than those fed the mineral mixture, exhibiting higher fat deposition in the beef cuts despite their similar weight (Table 2). Brisket point end and outside flat yield did not differ between MSGF and CG ( $p>0.05)$. Assessment of Longissimus dorsi (top sirloin) revealed that $\mathrm{pH}$ values were similar across treatments $(\mathrm{p}>0.05$; Table6) and within the range of 5.5 to 5.8 considered adequate for cattle beef (RAMOS; GOMIDE, 2009). 
The $\mathrm{pH}$ value is the main indicator of final meat quality since it has a significant effect on other variables, such as color, cooking loss and shearing force (RAMOS; GOMIDE, 2009). Meat from the different treatments showed similar cooking loss, shear force, $L^{*}(37.76)$, $a *(14.02)$ and $b *(11.52)$ values in the top sirloin $(\mathrm{p}>0.05)$.

Table 6. Meat quality and centesimal composition of Longissimus dorsi muscle (top sirloin) of Nellore steers on pasture submitted to different strategies of supplementation.

\begin{tabular}{|c|c|c|c|c|c|c|}
\hline \multirow{2}{*}{ Variables } & \multicolumn{4}{|c|}{ Treatments ${ }^{1}$} & \multirow{2}{*}{ C.V. $(\%)$} & \multirow{2}{*}{ P- Value } \\
\hline & MSGF & CG & $\mathbf{C F}$ & CGF & & \\
\hline \multicolumn{7}{|c|}{ Meat quality } \\
\hline $\mathrm{pH}$ & 5.57 & 5.56 & 5.74 & 5.62 & 2.55 & 0.074 \\
\hline $\mathrm{L}^{*}$ & 39.65 & 36.78 & 37.06 & 37.56 & 5.89 & 0.611 \\
\hline$a^{*}$ & 13.92 & 13.42 & 13.76 & 14.32 & 9.23 & 0.569 \\
\hline$b^{*}$ & 11.46 & 10.55 & 11.09 & 11.85 & 12.29 & 0.300 \\
\hline Marbling, score & 429.16 & 429.16 & 429.16 & 420.83 & 7.00 & 0.925 \\
\hline Thawing losses, $\%$ & $8.85^{\mathrm{a}}$ & $5.58^{\mathrm{a}, \mathrm{b}}$ & $3.94^{b}$ & $8.68^{\mathrm{a}}$ & 41.86 & 0.003 \\
\hline Cooking losses, $\%$ & 24.12 & 25.92 & 24.86 & 26.66 & 20.84 & 0.782 \\
\hline Shear force, $\mathrm{kgF} . \mathrm{cm}^{-3}$ & 10.56 & 11.61 & 9.74 & 10.29 & 23.45 & 0.503 \\
\hline \multicolumn{7}{|c|}{ Centesimal composition } \\
\hline Dry matter, $\%$ & 23.01 & 23.13 & 23.22 & 23.71 & 2.86 & 0.185 \\
\hline Ashes, $\%$ & $4.68^{b}$ & $4.88^{\mathrm{b}}$ & $5.93^{\mathrm{a}}$ & $5.38^{\mathrm{a}, \mathrm{b}}$ & 11.93 & 0.002 \\
\hline Crude protein, $\%$ & $90.74^{\mathrm{a}}$ & $90.68^{a}$ & $87.46^{\mathrm{b}}$ & $85.20^{\mathrm{b}}$ & 2.53 & $<0.001$ \\
\hline Ether extract, \% & $3.63^{\mathrm{b}}$ & $3.03^{b}$ & $3.57^{b}$ & $5.54^{\mathrm{a}}$ & 30.36 & 0.001 \\
\hline
\end{tabular}

${ }^{1}$ Supplementation with mineral salt on growth and finishing phases (MSGF), Supplementation with concentrate on growth phase (CG), supplementation with concentrate on finishing phase (CF) and supplementation with concentrate on growth and finishing phases (CGF). Averages in the same line, followed by different letters, differ from each other by the Tukey test at the 5\% level. C.V : coefficient of variation.

Meat was bright red in all the treatments, and the color parameters were close to those described by Sañudo et al. (2000) as normal for beef cattle ( $\mathrm{L}^{*}$ from 30.03 to 49.47 , a* from 8.24 to 23.53 and $\mathrm{b}^{*}$ from 3.38 to 12.10). Polizel Neto et al. (2009) reported similar results for cooking loss (24.31\%), $\mathrm{L}^{*}$ (34.1) and $\mathrm{a}^{*}$ (16.47), but not for shearing force $\left(6.04 \mathrm{~kg} . \mathrm{cm}^{-3}\right)$, indicating different tenderness.

The average marbling score (431.77) was similar across treatments $(p>0.05)$. This indicates that the meats contained low intramuscular fat, which was classified as trace according to the scale for beef Quality Grade USDA(1997). The result was expected because zebuine cattle exhibit low intramuscular fat deposition, even at the advanced developmental stage. Thawing losses in the Longissimus dorsi muscle were lower in CG than in MSGF and CGF $(\mathrm{p}<0.05)$, and similar between MSGF and CGF ( $>0.05$ ). In $\mathrm{CF}$, thawing loss was similar to that observed in MSGF and CGF ( $\mathrm{p}>0.05)$.

In general, thawing loss is not affected by supplementation, but is associated with $\mathrm{pH}$, which was similar across treatments $(p>0.05)$. As such, other factors, including storage period and temperature, freezing temperature and thawing time, likely affected thawing losses and increased the coefficient of variation. Cooking loss was not affected by the supplementation strategies tested ( $>0.05$ ), and the mean value of $25.46 \%$ can beconsidered normal. 
Polizel Neto et al. (2009) found no effects of cattle supplements on cooking loss, obtaining nearly $24.3 \%$ for Nellore cattle beef. According to Lombardi-Boccia et al. (2005), cooking loss is an important variable that can compromise nutrient availability in meat. Shear force in top sirloin did not differ across treatments ( $>0.05)$ and the average of $9.72 \mathrm{kgFcm}^{-3}$ obtained classifies the meat between tough and tender. Cattle beef with shearing force of up to $5 \mathrm{kgFcm}^{-3}$ is considered tender (LUCHIAIRI FILHO, 2000). The low SFT content of the meats evaluated likely contributed to the faster freezing of carcass muscles and fiber stiffening, thereby decreasing meat tenderness.

With regards to the proximate composition, dry matter levels did not differ across treatments $(p>0.05)$, but mineral matter, crude protein and ether extract varied as a function ofsupplementation strategy $(p<0.05)$. Steers from MSGF, which received mineral supplementation in the growth and finishing phases, while those from the CGfed concentrate only in the growth phase, showed higher crude protein levels in the Longissimus dorsi muscle compared to calves from CF and CGF $(\mathrm{p}<0.05)$; an inverse response was observed for mineral matter.

The proportion of carcass muscle was similar across treatments (Table 4), and although MSGF calves exhibited low energy intake and low growth rates (ROSA, 2016), they met their nutritional demands, maintaining the natural deposition sequence of tissue production (bones $>$ muscle $>$ fat), and the developmental curve for bones and muscle, thereby reducing energy use for fat deposition. This explains the lower ether extract levels in the top sirloin of calves from MSGF and CG compared to CGF $(\mathrm{p}<0.05)$.

The higher ether extract deposition in calves from CGF is due to the larger proportion of carcass fat (Table4), as previously discussed. Ether extract levels were similar in treatments MSGF, CG and CF ( $>0.05)$. According to Luchiari Filho (2000), a normal proximate composition for calf muscle is $74 \%$ moisture, $21 \%$ protein, $4 \%$ fat and $1 \%$ minerals. According to this author, however, several factors affect calf muscle composition, including animal age, the muscle evaluated and diet, and fat is the component that varies most.

In general, irrespective of supplementation level, the carcasses of Nellore calves slaughtered at 450 $\mathrm{kg}$ met the quality demanded by slaughterhouses. Despite the low tenderness, which is an intrinsic feature of the breed, the meat was lean, bright red, and resulted in an adequate cut yield for sale tothe slaughterhouses.

\section{Conclusions}

The use of feeding strategies on pasture with concentrate supplementation in the growth and finishing phases of Nellore cattle anticipates slaughter in 92 days than mineral supplementation, improves the meat composition and produces carcasses with satisfactory traits.

The selection of supplementation strategy and type of supplement (mineral or concentrate) in each production phase (growth and/or fattening) depends on the farmers' objectives and economic factors, primarily their production costs.

\section{References}

AMERICAN MEAT SCIENCE ASSOCIATION AMSA. Research guidelines for cookery sensory and instrumental tenderness measurement of fresh meat. Chicago, 1995. 48 p.

ASSOCIATION OF OFFICIAL ANALYTICAL CHEMISTRY - AOAC. Official Methods of Analysis. $16^{\text {th }}$ ed. Arlington: AOAC International, 1995. $1025 \mathrm{p}$.

BARIONI, C. E. S.; LANA, R. P.; MANCIO, A. B.; QUEIROZ, A. C.; SVERZUT, C. B.; MENDONÇA, B. P. C. Desempenho de novilhos suplementados e terminados em pasto na seca e avaliação do pasto. Arquivo Brasileiro de Medicina Veterinária e Zootecnia, Viçosa, MG, v. 62, n. 2, p. 373-381, 2010. DOI: 10.1590/ S0102-09352010000200018 
BRASIL. Portaria $\mathrm{n}^{\circ}$. 612, de 5 de Outubro de 1989. Sistema Nacional de tipificação de carcaças bovinas. Brasília: Ministério da Agricultura, 1989. 112 p.

CASAGRANDE, D. R.; AZENHA, M. V.; VIEIRA, B. R.; RESENDE, F. D.; FARIA, M. H.; BERCHIELLI, T. T.; RUGGIERI, A. C.; REIS, R. A. Performance and carcass quality of feedlot- or pasture-finished Nellore heifers according to feeding managements in the post weaning phase. Revista Brasileira de Zootecnia, Viçosa, MG, v. 42, n. 12, p. 899-908, 2013. DOI: 10.1590/S151635982013001200010

HANKINS, O. G.; HOWE, P. E. Estimation of the composition of beef carcasses and cuts. Washington:United States Department of Agriculture, 1946. 926 p. (Technical Bulletin).

LOMBARDI-BOCCIA, G.; LANZI, S.; AGUZZI, A. Aspects of meat quality: trace elements and B vitamins in raw and cooked meats. Journal of Food Composition and Analysis, San Diego, v. 18, n. 1, p. 39-46, 2005. DOI: 10.1016/j.jfca.2003.10.007

LUCHIARI FILHO, A. Pecuária da carne bovina. São Paulo: A. Luchiari Filho, 2000. 134 p.

MACHADO, P. A. S.; VALADARES FILHO, S. C.; VALADARES, R. F. D.; PAULINHO, M. F.; PAULINHO, P. V. R.; MARCONDES, M. I. Desempenho e exigências de energia e proteína de bovinos de corte em pasto suplementados. Arquivo Brasileiro de Medicina Veterinária e Zootecnia, Viçosa, MG, v. 64, n. 3, p. 683692, 2012. DOI: 10.1590/S0102-09352012000300021

MOREIRA, P. S. A.; BERBER, R. C. A.; LOURENÇO, F. J.; BELUFI, P. R.; KONRAD, M. Efeito do sexo e da maturidade sobre o peso de carcaça quente, acabamento e conformação de bovinos em Sinop-MT. Comunicata Scientiae, Teresina, v.3, n.4, p.292-298, 2012. DOI: 10.14295/cs.v3i4

MULLER, L. Normas para avaliação de carcaças e concurso de carcaças de novilhos. 2. ed. Santa Maria: Universidade Federal de Santa Maria, 1987. 31p.

NUTRIENT REQUERIMENTS COUNCIL - NRC. Nutrient requirements of beef cattle. $7^{\text {th }}$ ed.Washinton: National Academy of Sciences, 2000. 242p.

OWENS, F. N.; DUBESKI, P.; HANSON, C. F. Factors that the growth and development of ruminants. Journal of Animal Science, Savoy, v. 71, n. 11, p. 3138-3150, 1993. DOI: $10.2527 / 1993.71113138 x$
PEREIRA, P. M. R. C.; PINTO, M. F.; ABREU, U. G. P.; LARA, J. A. F. Características de carcaça e qualidade de carne de novilhos super precoces de três grupos genéticos. Pesquisa Agropecuária Brasileira, Brasília, v.44, n.11, p.1520-1527, 2009. DOI: 10.1590/s0100$204 \times 2009001100021$

POLIZEL NETO, A.; JORGE, A. M.; MOREIRA, P. S. A.; GOMES, H. F. B.; PINHEIRO, R. S. R. Desempenho e qualidade da carne de bovinos Nelore e F1 Brangus $\times$ Nelore recebendo suplemento com cromo complexado à molécula orgânica na terminação a pasto. Revista Brasileira de Zootecnia, Viçosa, MG, v. 38, n. 4, p. 737 745, 2009. DOI: 10.1590/s1516-35982009000400021

RAMOS, E. M.; GOMIDE, L. A. M. Avaliação da qualidade de carnes: fundamentos e metodologias. Viçosa, MG: Editora UFV, 2009.

ROSA, E. P. Estratégias de suplementação alimentas para produção de bovinos de corte em pastejo. 2016. Dissertação (Mestrado em Ciência Animal) Universidade Estadual de Mato Grosso do Sul, Mato Grosso do Sul, Aquidauana.

SALES, M. F. L.; PAULINO, M. F.; VALADARES FILHO, S. C.; FIGUEIREDO, D. M.; PORTO, M. O.; DETMANN, E. Supplementation levels for growing beef cattle grazing in the dry-rainy transition season. Revista Brasileira de Zootecnia, Viçosa, MG, v. 40, n. 4, p. 904911, 2011. DOI: 10.1590/s1516-35982011000400027

SAÑUDO, C.; ENSER, M. E.; CAMPO, M. M.; NUTE, G. R.; MARÍA, G.; SIERRA, I.; WOOD, J. D. Fatty acid composition and fatty acid characteristics of lamb carcass from Britain and Spain. Meat Science, Barking, v. 54 , n. 4 , p. $339-346,2000$. DOI: 10.1016/s03091740(99)00108-4

SILVA, J. J.; SILVA, C. G. M.; SOUSA, D. P.; PAULA, N. F.; CARVALHO, A. P. S.; MACEDO, B. G.; COSTA JÚNIOR, W. S.; BIANCHI-ZANETTE, I. E.; COSTA, R. V.; TEOBALDO, R. W. Supplementation strategies for dairy cows kept in tropical Grass pastures. Semina: Ciências Agrárias, Londrina, v. 38, n. 1, p. 401-406, 2017. DOI: $10.5433 / 1679-0359.2017 \mathrm{v} 38 \mathrm{n} 1 \mathrm{p} 401$

STATISTICAL ANALYSIS SYSTEM INSTITUTE SAS Institute. Statistical Analysis System.SAS versão 9.2. Cary: SAS Inst. Inc.,2009.

UNITED STATES DEPARTMENT OF AGRICULTURE - USDA. Official United States Standards for grades of carcass beef. Washington: Agriculture Marketing Services - United States Department of Agriculture, 1997. 
